\title{
Jurnal
}

p-ISSN 2621-797X ; e-ISSN 2746-6841 DOI:10.32493

Jurnal Disrupsi Bisnis, Vol. 4, No. 4, Juli 2021 (327-341)

http://openjournal.unpam.ac.id/index.php/DRB/index

\section{Analisa Marketing Mix Dan Lingkungan Sosial Terhadap Keputusan Pembelian Online Pakaian Wanita (Studi pada Konsumen Online Shop di Kota Bima)}

\author{
Nurasyiah', Herry Nurdin² \\ ${ }^{1,2}$ Program Studi Manajemen, STIE, Bima, Nusa Tenggara Barat,Indonesia \\ nhurulkasturi@gmail.com ${ }^{1 *}$, herrynurdin.stiebima@gmail.com ${ }^{2}$
}

Received 05 Juni 2021| Revised 20 Juni 2021 | Accepted 25 Juli 2021

*Korespondensi Penulis

\begin{abstract}
Abstrak
Perilaku pelanggan online shop merupakan hal yang masih menarik untuk diteliti. Oleh sebab itu penelitian ini dilakukan untuk menguji pengaruh marketing mix yang terdiri dari produk, harga, promosi dan lingkungan sosial terhadap keputusan pembelian online pakaian wanita di Kota Bima. Penelitian ini merupakan penelitian kuantitatif dengan metode asosiatif. Populasi pada pnelitian ini yaitu konsumen yang melakukan pembelian online dengan menggunakan rumus Unknown Populations, maka jumlah sampel pada penelitian ini yaitu 100 orang. Teknik sampel yang digunakan yaitu Accidental Sampling. Instrumen penelitian yaitu kuisioner yang telah diuji validitas dan uji reliabilitasnya. Data dianalisis dengan menggunakan asumsi klasik, persamaan regresi linier berganda, koefisien determinasi (R2), uji $\mathrm{t}$ dan uji F. Hasil penelitian menunjukkan bahwa secara parsial variabeel produk berpengaruh tidak signifikan terhadap keputusan pembelian online pakaian wanita di Kota Bima. Variabel Harga, Promosi dan Lingkungan Sosial secara parsial berpengaruh positif dan signifikan terhadap keputusan pembelian online pakaian wanita di Kota Bima. Produk, Harga, Promosi dan Lingkungan sosial secara bersamasama (simultan) berpengaruh positif dan signifikan terhadap keputusan pembelian online pakaian wanita di Kota Bima dengan nilai sig 0,000 $(0,000<24.037)$. Hal ini menunjukkan bahwa apabila onlineshop memberikan produk yang berkualitas dengan harga yang terjangkau serta melakukan promosi yang menarik minat pembeli, maka akan semakin meningkat keputusan konsumen melakukan pembelian online.
\end{abstract}

Kata Kunci: Produk, Harga; Promosi; Lingkungan Sosial; Keputusan Pembelian

\begin{abstract}
The behavior of online shop customers is something that is still interesting to study. Therefore, this study was conducted to examine the effect of the marketing mix consisting of product, price, promotion and social environment on online purchasing decisions for women's clothing in Bima City. This research is a quantitative research with associative method. The population in this study are consumers who make online purchases using the Unknown Populations formula, so the number of samples in this study is 100 people. The sampling technique used is Accidental Sampling. The research instrument is a questionnaire that has been tested for validity and reliability. The data were analyzed using classical assumptions, multiple linear regression equations, coefficient of determination (R2), $t$ test and $F$ test. The results showed that partially product variables had no significant effect on online purchasing decisions for women's clothing in Bima City. The variables of Price, Promotion and Social Environment partially have a positive and significant effect on online purchasing decisions for women's clothing in Bima City. Product, price, promotion and social environment together (simultaneously) have a positive and significant effect on online purchasing decisions for women's clothing in Bima City with a sig value of 0.000 $(0.000<24.037)$. This shows that if the online shop provides quality products at affordable prices and carries out promotions that attract buyers, it will increase consumer decisions to make online purchases.
\end{abstract}

Keywords: Product; Price; Promotion; Social Environment; Purchase Decision 


\section{PENDAHULUAN}

Seiring dengan perkembangan jaman perubahan yang terjadi dilingkungan secara signifikan, berlansung cepat. Terutama kemajuan teknologi membuat semuanya lebih mudah.segala sesuatu yang diinginkan lebih cepat untuk didapatkan dengan melalui internet. Dengan meningkatnya penetrasi internet di Indonesia memunculkan pergeseran teknologi pemasaran. Hal ini juga mempengaruhi dunia online mengalami perubahan yang sangat cepat. Sehingga konsumen yang biasa berbelanja di toko-toko kini beralih kedunia online. Bahkan toko-toko offline melakukan promosi lewat online agar tidak ketinggalan. Perubahan perilaku supplier atau konsumen menjadi salah satu pendorong perubahan dalam bidang strategi pemasaran yang dilakukan perusahaan.

Sebagaimana yang diketahui bahwa saat ini konsumen sangat kritis dalam memilih suatu produk, hingga pada saat memutuskan akan memilih dan membeli produk yang mereka inginkan dan sama-sama kita ketahui bahwa produk yang ditawarkan di pasaran saat ini, baik yang Online maupun yang Offline sangat banyak ragam dan variasi bentuknya, tidak terkecuali untuk produk pakaian.Untuk produk pakaian, konsumen lebih cenderung memperhatikan desainnya, di mana pilihan desain yang semakin banyak ini membuat konsumen dapat menentukan pilihannya akan suatu produk pakaian yang membuat mereka terpikat dan membeli produk tersebut.Menurut Kotler dan Keller (2013) Keputusan pembelian yaitu tahap evaluasi konsumen membentuk preferensi antar merek dalam kumpulan pilihan.

Istilah marketing mix (bauran pemasaran) digunakan pertama kali oleh Neil Borden yang terinspirasi dari gagasan James Cullington. Gagasanya adalah bahwa seorang eksekutif bisnis berperan sebagai “mixer of ingredients". Marketing mix menurut Kotler dan Amstrong (2014) adalah sekumpulan variabel-variabel marketing, yang digunakan oleh perusahaan untuk mengejar target penjualan yang diinginkan. Jadi dapat disimpulkan bahwa marketing mix merupakan strategi pemasaran yang dilaksanakan secara terpadu atau strategi pemasaran yang dilakukan secara bersamaan.strategi tersebut digunakan dengan menerapkan elemen strategi yang ada dalam marketing mix itu sendiri. Mengingat pembahasan tentang marketing mix dimasa yang silam yaitu penggunaan teknik $4 \mathrm{P}$ pada teorinya, penulis hanya mengambil 3 poin saja dari 4 gagasan yang dikembangkan yaitu produc, price dan promotion. Produc (produk) adalah segala sesuatu yang mampu dihasilkan dari proses produksi berupa barang atau jasa yang nantinya bida diperjual belikan dipasar. Menurut Abdullah dan Francis (2016:153) menyatakan "Produk adalah segala sesuatu yang dapat ditawarkan ke pasar untuk mendapatkan perhatian, dibeli, dipergunakan, atau dikonsumsi dan yang dapat memuaskan keinginan atau kebutuhan."Dalam melakukan pembelian produk, konsumen tidak hanya membeli fisik dari produk itu saja, melainkan juga membeli manfaat dan nilai dari suatu produk

Setelah mengidentifikasi produk, konsumen juga akan melakukan perbandingan terhadap harga dari produk yang akan mereka beli nantinya. Hal ini dapat konsumen lakukan karena banyaknya pesaing yang menawarkan berbagai macam varian harga dipasaran, terutama pada Online shop. Konsumen hanya cukup membuka atau mengunjungi beberapa aplikasi Online shop untuk membandingkan harga produk yang satu dengan yang lainnya. Harga bisa diartikan sebagai suatu nilai mata uang guna untuk melakukan pembayaran yang dilakukan konsumen untuk mendapatkan produk yang diinginkan (Marina, dkk, 2016)

Selain memperhatikan produk dan harga. Produsen atau perusahaan juga harus melakukan promosi terhadap produk yang mereka pasarkan, agar konsumen mengetahui, produk apa yang sedang dipasarkan oleh suatu perusahaan. Menurut pendapat Amelia, dkk (2013) Promosi adalah aktivitas yang mengkomunikasikan hubungan antara produk dan membujuk target konsumen untuk membelinya. Hal ini sejalan dengan pendapat Hesty (2018) yang menyatakan promosi merupakan media untuk mengenalkan, mengajak, mempersuasi, dan mempengaruhi konsumen untuk mempertimbangkan, 
membeli dan konsumsi produk yang ditawarkan oleh perusahaan atau pemasar. Sedangkan untuk place (tempat) tidak dimasukkan dalam penelitian ini karena dianggap umum oleh penulis. Didalam melakukan transaksi jual beli online kita bisa memilih tempat dimana saja sesuai dengan waktu luang owner dan customer.

Adapun lingkungan sosial merupakan tempat berlangsungnya aktifitas sehari-hari. Lingkungan sosial menjadi faktor penentu terhadap perubahan-perubahan perilaku yang terjadi pada setiap individu atau kelompok. Lingkungan keluarga, teman sebaya, serta lingkungan tempat tinggal akan membentuk perilaku dalam diri setiap individu. Lingkungan sosial yang baik akan membentuk pribadi baik, karena perilaku dan kepribadian seseoarang cerminan dari lingkungan sosial yang mereeka tempati. Tidak hanya perusahaan, pihak konsumen juga memiliki pengaruh yang cukup besar dalam mengambil keputusan. Dimana, lingkungan sosial konsumen juga ikut mempengaruhi ketika konsumen hendak mempertimbangkan keputusan. Seperti, pengalaman seorang teman, pengaruh tetangga, rekan kerja bahkan keluarga mereka sendiri. Karena, pengaruh keluarga dapat menjadi faktor yang signifikan dalam pembelian produk. Lingkungan sosial adalah semua interaksi sosial antara masyarakat, baik secara langsung, maupun secara vicarious. Dimana vicarious ialah pengamatan mengenai apa yang sedang dilakukan atau dikenakan orang lain Olson (2013) dalam (Hartiyani, 2017).

Konsumen memperoleh banyak manfaat dengan berbelanja secara online, yaitu lebih nyaman, produk lebih beragam, transaksi lebih cepat dan tanpa antrian, rahasia konsumen terlindungi,dan dapat menghemat waktu, tenaga dan biaya. Selain itu berbelanja online juga memiliki kelemahan, yaitu minimnya bantuan saat berbelanja dimana konsumen tidak dapat melakukan kontak fisik secara langsung dengan penjual,selain itu produk juga tidak bisa diraba dan dicoba. Dari fakta-fakta diatas, penelitian tentang perilaku pelanggan akan selalu dilakukan karena merupakan dasar dari pengambilan keputusan pembelian konsumen. Hal ini sesuai dengan penelitian sebelumnya dari Gusrita, Desy (2019) menguji pengaruh marketing mix dan lingkungan sosial terhadap keputusan pembelian online pakaian wanita di Kota Padang.. Hasil penelitian ini menunjukkan bahwa Produk, harga, tempat, promosi dan lingkungan sosial berpengaruh signifikan terhadap keputusan pembelian online pakaian wanita di Kota Padang.

Berdasarkan latar belakang serta penelitian sebelumnya, sehingga peneliti menganggap bahwa perilaku pelanggan toko online merupakan hal yang masih menarik untuk diteliti. Oleh sebab itu penelitian tentang Analisa Marketing Mix Dan Ligkungan Sosial Terhadap Keputusan Pembelian Online Pakaian Wanita Di Kota Bima perlu dilakukan untuk mengetahui apakah produk, harga, promosi dan lingkungan sosial berpengaruh terhadap keputusan pembelian online pakaian wanita di Kota Bima.

\section{Produk}

Menurut Kotler dan Keller (2016) produk merupakan sesuatu yang ditawarkan sebagai usaha mencapai tujuan dari perusahaan, melalui pemenuhan kebutuhan dan keinginan konsumen. Menurut Saladin (2016) produk adalah segala sesuatu yang dapat ditawarkan kepasar untuk mendapatkan perhatian, dibeli, dipegunakan, atau dikonsumsi, dan yang dapat memuaskan keinginan dan kebutuhan. Adapun indikator dari produk adalah sebagai berikut:

a. Atribut produk adalah suatu komponen yang merupakan sifat-sifat produk yang menjamin agar produk tersebut dapat memenuhi kebutuhan dan keinginan yang diharapkan konsumen.

b. Variasi produk dapat diartikan sebagai produk yang memiliki desain atau jenis berbeda dan diproduksi oleh perusahaan.

c. Cita rasa merupakan kompleks sensasi yang ditimbulkan oleh berbagai indera (penciuman, pengecap, penglihatan, peraba dan pendengaran) pada waktu mengkonsumsi makanan.

d. Kualitas produk adalah kualitas meliputi usaha memenuhi atau melebihi harapan pelanggan,kualitas mencakup produk, jasa, manusia, proses dan lingkungan. 


\section{Harga}

Harga merupakan unsur terpenting kedua dalam bauran pemasaran setelah produk dan merupakan satu-satunya unsur dalam bauran pemasaran yang menghasilkan pendapatan penjualan, sedangkan unsur-unsur lainnya merupakan pengeluaran biaya saja. Keputusan-keputusan mengenai harga mencakup tingkat harga, potongan harga, keringanan periode pemasaran, dan rencana iklan yang dibuat oleh produsen. Menurut Kotler dan Armstrong (2016) harga merupakan jumlah uang yang harus dibayar pelanggan untuk memperolah produk. Menurut Alma (2011), harga adalah satuan moneter atau ukuran lainya (termasuk barang dan jasa lainya) yang ditukarkan agar memperoleh hak kepemilikan atau penggunaan suatu barang dan jasa sehingga menimbulkan kepuasaan konsumen. Menurut Kotler (2016) indikator yang digunakan untuk mengukur harga, yaitu:

a. Keterjangkauan harga produk.

Kemampuan daya beli konsumen atas produk yang dibelinya.

b. Kesesuaian harga dengan kualitas produk

Harga merupakan salah satu indikator dalam menentukan suatu kualitas barang itu sendiri. Tidak selalu harga yang mahal itu menunjukan bahwa kualitas dari barang tersebut adalah bagus.

c. Daya saing harga produk

Kemampuan suatu produk untuk bersaing dengan produk sejenisnya dipasaran dengan harga yang telah ditetapkan oleh perusahaan, meskipun harga yang ditawarkan lebih tinggi dibandingkan dengan produk sejenis.

d. Kesesuaian harga dengan manfaat produk

Harga yang mahal tidak menjadi persoalan untuk suatu produk apabila berbanding lurus dengan manfaat yang dapat diperoleh dari membeli produk tersebut.

\section{Promosi}

Menurut Herman Malau (2017) mengatakan bahwa : Promosi adalah bentuk persuasi langsung melalui penggunaan berbagai insentif yang dapat diatur untuk merangsang pembelian produk dengan segera dan atau meningkatkan jumlah yang dibeli pelanggan serta membuat konsumen puas sehingga melakukan pembelian kembali. Menurut Lupiyoadi (2014) mendefinisikan pengertian produk yaitu: Promosi adalah kegiatan yang dilakukan perusahaan untuk mengkomunikasikan manfaat produk dan sebagai alat untuk mempengaruhi konsumen dalam kegiatan pembelian atau penggunaan jasa sesuai dengan kebutuhan.

Berdasarkan definisi menurut beberapa ahli, maka penulis sampai pada pemahaman bahwa promosi adalah aktivitas untuk mengkomunikasikan keunggulan produk atau jasa yang dimiliki oleh perusahaan sehingga menarik perhatian, menciptakan keputusan pembelian dan memberikan kepuasan sehingga konsumen akan melakukan pembelian ulang. Lima indikator Promosi menurut (Kotler dan Amstrong, 2014) adalah:

1. Periklanan adalah komunikasi non personal mengenai produk, ide, jasa, yang dibayar oleh sponsor

2. Promosi penjualan merupakan kunci utama dalam kampanye pemasaran, terdiri dari kumpulan alat insentif, yang sebagian besar bersifat jangka pendek, dirancang untuk merangsang pembelian produk atau layanan tertentu dengan lebih cepat atau lebih oleh konsumen atau perdagangan.

3. Hubungan masyarakat dan publisitas

Publisitas juga sering disebut hubungan masyarakat. Publisitas merupakan aktivitas perusahaan yang dirancang untuk memicu perhatian media melalui artikel, editorial dan berita baru yang diharapkan dapat memelihara kesadaran, cara pandang dan citra yang dipikirkan masyarakat terhadap perusahan menjadi tetap positif.

4. Penjualan pribadi

Personal selling (penjualan pribadi) komunikasi langsung (tatap muka) antara penjual dengan calon pelanggan untuk memperkenalkan suatu produk kepada calon pelanggan dan membentuk 
pemahaman pelanggan terhadap produk sehingga pelanggan kemudian akan mencoba dan membelinya.

5. Pemasaran langsung adalah bagaimana anda melahirkan suatu kontak langsung dengan pelanggan anda dan pelanggan potensial anda dalam melakukan kampanye iklan layanan atau produk.

\section{Lingkungan Sosial}

Lingkungan sosial adalah wilayah yang menjadi tempat berlangsungnya berbagai interaksi sosial antara berbagai kelompok dan pranatanya dengan symbol dan nilai juga norma yang ditetapkan juga berkaitan dengan lingkungan alam dan lingkungan binaan atau lingkungan buatan (tata ruang), Purba (2012). Lingkungan soial adalah individu atau kumpulan lain yang berada didekat kehidupan masyarakat, laksana tetangga, teman-teman termasukpun orang beda disekitarnya yang belum dikenal atau masyrakat umum diluar lingkungan sekitar. Menurut Ensiklopedia Amerika lingkungan adalah faktor-faktor yang menyusun lingkungan selama organisme, khususnya kompenen-komponen yang memprovokasi perilaku, dan kelestarian organisme. Adapun Indikator lingkungan sosial menurut Kotler (2012) adalah:

a. Kelompok acuan yaitu kelompok acuan seseorang terdiri dari semua kelompok yang memiliki pengaruh langsung (tatap muka) atau tidak langsung sikap atau perilaku seseorang.

b. Keluarg adalah kelompok yang terdiri dari dua atau lebih orang yang berhubungan melalui darah, perkawinan, atau adopsi dan tinggal bersama.

c. Peran dan status

Peran meliputi kegiatan yang diharapkan akan dilakukan oleh seseorang. Masing-masing peran menghasilkan status.

\section{Keputusan Pembelian}

Keputusan pembelian menurut Schiffman dan Kanuk dalam jurnal Pertiwi, dkk (2016) adalah seleksi terhadap dua pilihan alternative atau lebih. Menurut Sudaryono (2014) mendefinisikan keputusan pembelian sebagai suatu pemilihan tindakan dari dua atau lebih pilihan alternative. Keputusan pembelian adalah keputusan pembelian tentang pilihan produk yang akan dibeli. Menurut Kotler dan Amstrong (2013) indikator variabel keputusan pembelian adalah:

a. Keputusan tentang produk adalah produk yang relativ tidak mahal yang dibeli dan dikonsumsi secara cepat dan teratur.

b. Penentuan pembelian sesuai dengan kebutuhan

Setiap pembelian konsumen tercipta karena adanya kebutuhan keperluan atau keinginan atau campuran keduanya.

c. Penentuan keputusan pembelian yaitu pemikiran dimana individu mengevaluasi berbagai pilihan dan memutuskan pilihan pada suatu produk dari sekian banyak pilihan.

d. Perasaan setelah membeli adalah perasaan yang individu rasakan setelah menggunakan suatu produk, puas atau tidak puas.

\section{Kerangka Pemikiran}

Banyak faktor yang dapat mempengaruhi keputusan pembelian suatu produk bagi konsumen diantaranya adalah produk, harga, promosi, tempat dan lingkungan sosial. Pengaruh Produc, Price, Promotion dan Lingkungan sosial terhadap keputusan pembelian online pakaian wanita secara sistematis dapat digambarkan sebagai berikut: 


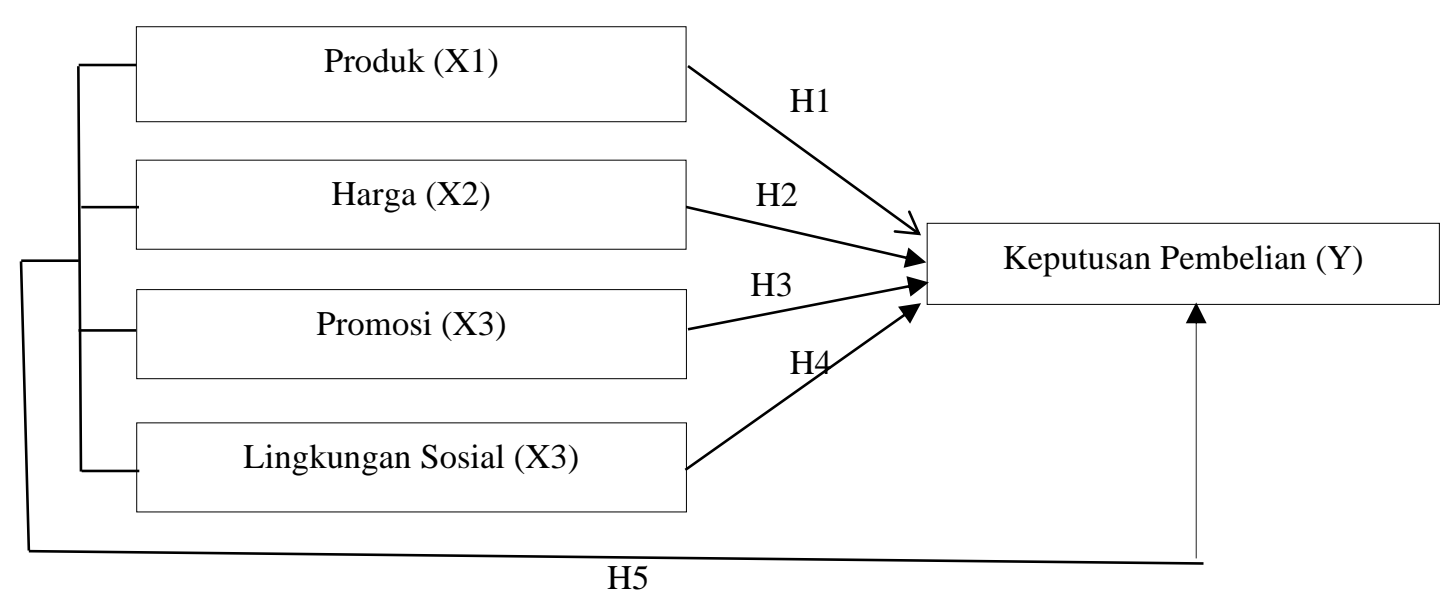

\section{Hipotesis Penelitian}

Gambar 1. Kerangka Pemikiran

Hipotesis merupakan dugaan atau jawaban sementara terhasil hasil penelitian (Sugiyono, 2016). Dari penjabaran kerangka pikir serta keterkaitan antara variabel Produc, Price, Promotion dan Lingkungan sosial berpengaruh terhadap keputusan pembelian online pakaian wanita di atas, maka hipotesis pada penelitian adalah:

H1 : Produk berpengaruh positif dan signifikan terhadap keputusan pembelian online pakaian wanita di Kota Bima

H2 : Harga berpengaruh positif dan signifikan terhadap keputusan pembelian online pakaian wanita di Kota Bima

H3 : Promosi berpengaruh positif dan signifikan terhadap keputusan pembelian online pakaian wanita di Kota Bima

H4 : Lingkungan sosial berpengaruh positif dan signifikan terhadap keputusan pembelian online pakaian wanita di Kota Bima

H5 : Produk, Harga, Promosi dan Lingkungan sosial berpengaruh terhadap keputusan pembelian online pakaian wanita di Kota Bima.

\section{METODE}

\section{Jenis Penelitian.}

Jenis penelitian ini termasuk penelitian asosiatif (pengaruh). Penelitian Asosiatif merupakan suatu pernyataan yang menunjukan dugaan tentang hubungan antara dua variabel atau lebih. (Sugiyono, 2016). Tujuan dari penelitian asosiatif adalah untuk memahami variabel mana yang berfungsi sebagai penyebab (variabel bebas) dan variabel mana yang berfungsi sebagai akibat (variabel tergantung) dan untuk menentukan karakteristik hubungan antara variabel penyebab dan efek yang akan di prediksi, penelitian ini menggunakan pendekatan kuantitatif, yaitu penelitian yang menitikberatkan pada pengujian hipotesis. Oleh karena itu penulis ingin mengetahui pengaruh dari variabel produk, harga, promosi, dan lingkungan sosial terhadap keputusan pembelian online pakaian wanita di Kota Bima.

\section{Populasi dan Sampel}

Populasi adalah wilayah generalisasi yang terdiri atas obyek/subyek yang mempunyai kualitas dan karakteristik tertentu ditetapkan oleh peneliti untuk dipelajari dan kemudian ditarik kesimpulan (Sugiyono, 2016). Adapun populasi dari penelitian ini adalah konsumen yang sudah pernah berbelanja dan akan berbelanja online di online shop.Sampel adalah bagian dari jumlah dan karakteristik yang dimiliki oleh populasi tersebut, (Sugiyono, 2016). Teknik pengambilan sampel yang digunakan dalam penelitian ini adalah non probability sampling, dimana semua populasi tidak memiliki peluang yang 
sama untuk menjadi responden dan pengambilan sampel didasarkan pada pertimbangan peneliti (Simamora, 2014). Ukuran populasi dalam penelitian ini sangat banyak dan tidak dapat diketahui dengan pasti, oleh karena itu besar sampel dihitung dengan rumus Unknown Populations: (Frendy, 2011). Dari hasil perhitungan dengan rumus Unknown Populations, diperoleh jumlah sampel adalah sebesar 96 orang dan dibulatkan menjadi 100 orang responden/konsumen. Teknik pengambilan sampel menggunakan metode accidental sampling. Dimana menurut Sugiyono (2015) accidental sampling adalah mengambil responden sebagai sampel berdasarkan kebetulan, yaitu siapa saja yang secara kebetulan bertemu dengan peneliti dapat digunakan sebagai sampel bila orang yang ditemui cocok sebagai sumber data.

\section{Metode Pengumpulan Data}

Teknik pengumpulan data yang digunakan: (a) Observasi, yaitu melakukan pengamatan dan pencatatan secara sistematik terhadap gejala yang tampak pada objek penelitian, (b) Kuesioner merupakan teknik pengumpulan data yang dilakukan dengan cara memberi seperangkat pertanyaan atau pernyataan tertulis kepada responden untuk dijawabnya, (c) Penelitian pustaka yaitu penelitian yang dlakukan berdasarkan karya tulis, termasuk hasil penelitian baik yang telah maupun yang belum di publikasikan. Sedangkan Instrument penelitian yang digunakan adalah kuesioner dengan skala likert. Dengan alternative pilihan jawaban 1 sampai dengan 5. Adapun bobot skor jawaban yaitu: $5=$ sangat setuju, $4=$ setuju, $3=$ ragu-ragu, $2=$ tidak setuju dan $1=$ sangat tidak setuju.

\section{Teknik Analisis Data}

Teknik analisis data yang digunakan dalam penelitian ini adalah dengan melakukan analisis kuantitatif yang dinyatakan dengan angka-angka yang dalam perhitungannya menggunakan metode statistik yang dibantu dengan program pengolah data statistic SPSS versi 23.0. Metode-metode analisis yang digunakan meliputi: uji validitas, uji reliabilitas, uji asumsi klasik (uji Normalitas, uji multikolinearitas, uji autokorelasi , uji heteroskedastisitas), regresi linear berganda, pengujian parsial (uji t) dan pengujian simultan (uji f).

\section{HASIL DAN PEMBAHASAN}

\section{Uji Validitas}

Suatu item dikatakan valid apabila $r$ hitung lebih besar dari $r$ kritis. Besarnya $r$ tiap butir pertanyaan dapat dilihat dari hasil analisis pada kolom Corrected items atau total correlation.

Tabel 1. Uji Validitas

\begin{tabular}{ccccc}
\hline \multirow{2}{*}{ Variabel } & $\begin{array}{c}\text { Corrected } \\
\text { Items }\end{array}$ & $\begin{array}{c}\text { Total } \\
\text { Correlation }\end{array}$ & $\begin{array}{c}\text { Standard } \\
\text { Validitas }\end{array}$ & Keterangan \\
\hline \multirow{5}{*}{ Produk (X1) } & $\mathrm{X} 1.1$ & 0,462 & 0,300 & Validitas \\
\cline { 2 - 5 } & $\mathrm{X} 1.2$ & 0,452 & 0,300 & Validitas \\
\cline { 2 - 5 } & $\mathrm{X} 1.3$ & 0,468 & 0,300 & Validitas \\
\cline { 2 - 5 } X1.4 & 0,424 & 0,300 & Validitas \\
\cline { 2 - 5 } Harga (X2) & $\mathrm{X} 2.1$ & 0,574 & 0,300 & Validitas \\
\cline { 2 - 5 } & $\mathrm{X} 2.2$ & 0,439 & 0,300 & Validitas \\
\cline { 2 - 5 } & $\mathrm{X} 2.3$ & 0,432 & 0,300 & Validitas \\
\cline { 2 - 5 } Promosi (X3) & $\mathrm{X} 2.4$ & 0,392 & 0,300 & Validitas \\
\cline { 2 - 5 } & $\mathrm{X} 3.1$ & 0,482 & 0,300 & Validitas \\
\cline { 2 - 5 } & $\mathrm{X} 3.2$ & 0,588 & 0,300 & Validitas \\
\cline { 2 - 5 } & $\mathrm{X} 3.3$ & 0,523 & 0,300 & Validitas \\
\cline { 2 - 5 } & $\mathrm{X} 3.4$ & 0,525 & 0,300 & Validitas \\
\cline { 2 - 5 } & $\mathrm{X} 3.5$ & 0,571 & 0,300 & Validitas \\
\cline { 2 - 5 } & $\mathrm{X} 4.1$ & 0,565 & 0,300 & Validitas \\
\hline
\end{tabular}




\begin{tabular}{ccccc}
\hline $\begin{array}{c}\text { Lingkungan } \\
\text { Sosial (X4) }\end{array}$ & X4.3 & 0,464 & 0,300 & Validitas \\
\hline & & & & \\
\cline { 2 - 5 } & Y1 & 0,386 & 0,300 & Validitas \\
\cline { 2 - 5 } & Y3 & 0,587 & 0,300 & Validitas \\
\cline { 2 - 5 } Keputusan \\
\cline { 2 - 5 } Pembelian (Y) & Y4 & 0,492 & 0,300 & Validitas \\
\cline { 2 - 5 } & Y5 & 0,453 & 0,300 & Validitas \\
\cline { 2 - 5 } & Y6 & 0,526 & 0,300 & Validitas \\
\cline { 2 - 5 } & Y7 & 0,579 & 0,300 & Validitas \\
\cline { 2 - 5 } & Y8 & 0,564 & 0,300 & Validitas \\
\hline
\end{tabular}

Sumber : Data primer diolah peneliti, 2021

Hasil pengolahan data menunjukkan bahwa butir-butir pertanyaan yang digunakan untuk mengindentifikasi variabel bebas dan varibel terikat memiliki nilai total correlation yang lebih besar dari r-kritis. Dengan demikian seluruh indikator pada penelitian ini dapat dikatakan valid.

\section{Uji Reliabilitas}

Untuk mengetahui reliabel atau tidaknya suatu variabel maka dilakukan uji reliabilitas yaitu dengan membandingkan nilai dari cronbach's alpha dengan nilai standarisasi reliabel sebesar > 0,6. Hasil uji reliabilitas dapat disajikan pada tabel 2.

Tabel 2. Uji Reliabilitas

\begin{tabular}{lcccc}
\hline \multicolumn{1}{c}{ Variabel } & Total Item & $\begin{array}{c}\text { Cronbach's } \\
\text { Alpha }\end{array}$ & $\begin{array}{c}\text { Standard } \\
\text { Reliabel }\end{array}$ & Keterangan \\
\hline Produk & 4 & 0,776 & $>0,6$ & Reliabel \\
\hline Harga & 4 & 0,749 & $>0,6$ & Reliabel \\
\hline Promosi & 5 & 0,727 & $>0,6$ & Reliabel \\
\hline Lingkungan sosial & 3 & 0,746 & $>0,6$ & Reliabel \\
\hline Keputusan pembelian & 8 & 0,699 & $>0,6$ & Reliabel \\
\hline
\end{tabular}

Hasil uji reliabilitas diperoleh nilai cronbach's alpha variabel produk sebesar 0,776, harga sebesar 0,749 , promosi sebesar 0,727 , lingkungan sosial sebesar 0,746 , dan keputusan pembelian sebesar 0,699 dapat disimpulkan bahwa seluruh item-item indikator variabel adalah reliabel.

\section{Uji Asumsi Klasik}

\section{Uji Normalitas}

Uji Normalitas, bertujuan untuk menguji apakah suatu data berdistribusi normal atau tidak. Uji normalitas dengan Grafik P-Plot adalah sebagai berikut :

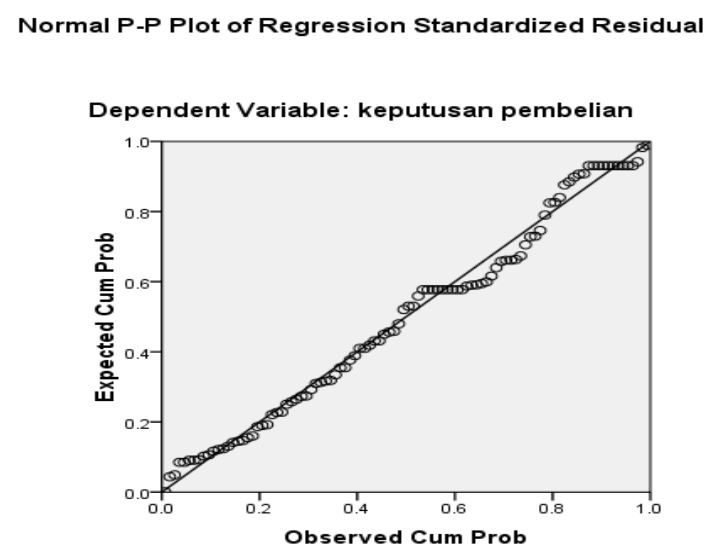

Gambar 1. Grafik P Plot

Dari grafik P-P Plot OF Regression standardized pada output SPSS diatas menunjukan bulatan kecil hitam mengukuti garis diagonal, dapat disimpulkan data penelitian ini berdistribusi normal, sehingga dapat digunakan untuk analisis berikutnya. 
Uji Multikolinearitas

Menurut Imam Ghozali (2016) tidak terjadi gejala multikolinearitas jika nilai tolerance $>0,100$ dan nilai VIF < 10,00. Hasil uji Multikolinearitas yaitu :

Tabel 3. Uji Multikolinearitas

Coefficients $^{a}$

\begin{tabular}{|c|c|c|c|c|c|c|c|c|}
\hline \multirow{2}{*}{\multicolumn{2}{|c|}{ Model }} & \multicolumn{2}{|c|}{$\begin{array}{c}\text { Unstandardized } \\
\text { Coefficients }\end{array}$} & \multirow{2}{*}{$\begin{array}{c}\begin{array}{c}\text { Standardized } \\
\text { Coefficients }\end{array} \\
\text { Beta }\end{array}$} & \multirow[t]{2}{*}{$\mathrm{T}$} & \multirow[t]{2}{*}{ Sig. } & \multicolumn{2}{|c|}{ Collinearity Statistics } \\
\hline & & B & Std. Error & & & & Tolerance & VIF \\
\hline \multirow[t]{5}{*}{1} & (Constant) & 8.392 & 2.644 & & 3.174 & .002 & & \\
\hline & Produk & .208 & .121 & .143 & 1.720 & .089 & .758 & 1.320 \\
\hline & Harga & .423 & .141 & .264 & 2.990 & .004 & 670 & 1.492 \\
\hline & Promosi & .331 & .106 & .272 & 3.114 & .002 & .685 & 1.460 \\
\hline & lingkungan social & .547 & .182 & .268 & 3.001 & .003 & .655 & 1.527 \\
\hline
\end{tabular}

a. Dependent Variable: Y

Sumber : Data primer diolah peneliti, 2021

Data output SPSS pada uji multikolinearitas menunjukan bahwa nilai VIF variabel (X1) adalah $1.320<10,00$ variabel $(\mathrm{XX})$ adalah $1.492<10,00$ variabel $(\mathrm{X} 3)$ adalah $1.460<10,00$ dan variabel $(\mathrm{X} 4)$ adalah 1.527<10,00. Dan nilai tolerance value variabel $(\mathrm{X} 1)$ 0,758>0,100 variabel (X2) 0,670>0,100 variabel (X3) 0,685>0,100 dan variabel (X4) 0,655>0,100. Dengan demikian diketahui bahwa nilai tolerance yang besarnya di atas 0,1 dan nilai VIF dibawah 10 menunjukkan bahwa tidak terdapat multikolineritas diantara variabel bebas, sehingga tidak terjadi pelanggaran asumsi multikolinearitas pada model persamaan regresi

Uji Heterokedastisitas

Hasil uji heterokedastisitas dengan scatterplot adalah sebagai berikut :

scatterplot

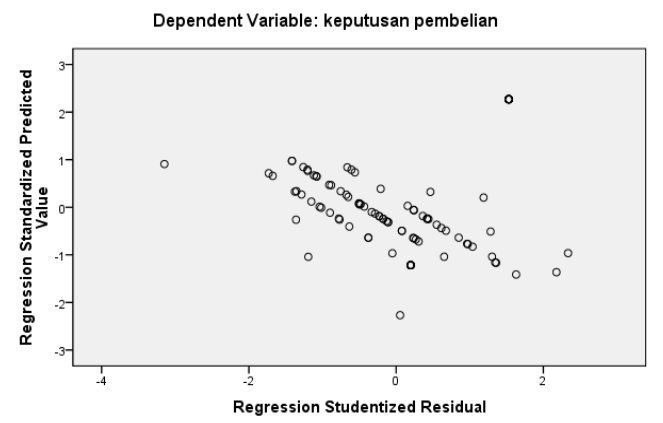

Gambar 2. Hail Uji Heterokedastisitas dengan Scatterplot

Bentuk gambar pada grafik diatas, menunjukan penyebaran residual adalahtidak teratur dan tidak membentuk pola. Hal tersebut dapat dilihat pada titik-titik atau plot yang menyebar. Sehingga kesimpulan yang dapat diambil yaitu tidak terjadi residual.

\section{Uji Autokorelasi}

Salah satu cara yang digunakan untuk mendeteksi ada atau tidaknya autokorelasi adalah dengan uji DurbinWatson. Hasil uji autokorelasi adalah sebagai berikut :

Tabel 4 : Hasil Uji Autokorelasi 
Model Summaryb

\begin{tabular}{|l|r|r|r|r|r|}
\hline Model & \multicolumn{1}{c|}{$\mathrm{R}$} & R Square & Adjusted R Square & Std. Error of the Estimate & \multicolumn{1}{c|}{ Durbin-Watson } \\
\hline 1 & $.709^{\mathrm{a}}$ & .503 & .482 & 1.69474 & 1.919 \\
\hline
\end{tabular}

a. Predictors: (Constant), X2, X1, X3, X4

b. Dependent Variable: Y

Sumber : Data primer diolah peneliti, 2021

Dari data tabel 4 di atas menunjukan nilai durbin-watson sebesar 1.919 lebih besar dari batas atas (du) yakni 1.780 dan lebih dari (4-du) 4-1.780=2,220 dapat disimpulkan bahwa data penelitian tidak terjadi autokorelasi

\section{Regresi Linear Berganda} berikut:

Ringkasan hasil pengolahan data dengan menggunakan software statistic SPSS 23.0 sebagai

Tabel 5. Regresi Linier Berganda

Coefficients $^{\text {a }}$

\begin{tabular}{|c|c|c|c|c|c|c|}
\hline \multirow{2}{*}{\multicolumn{2}{|c|}{ Model }} & \multicolumn{2}{|c|}{ Unstandardized Coefficients } & \multirow{2}{*}{$\frac{\text { Standardized Coefficients }}{\text { Beta }}$} & \multirow[b]{2}{*}{$\mathrm{t}$} & \multirow[b]{2}{*}{ Sig. } \\
\hline & & $\mathrm{B}$ & Std. Error & & & \\
\hline \multirow[t]{5}{*}{1} & (Constant) & 8.392 & 2.644 & & 3.174 & .002 \\
\hline & Produk & .208 & .121 & .143 & 1.720 & .089 \\
\hline & Harga & .423 & .141 & .264 & 2.990 & .004 \\
\hline & Promosi & .331 & .106 & .272 & 3.114 & .002 \\
\hline & Lingkungan Sosial & .547 & .182 & .268 & 3.001 & .003 \\
\hline
\end{tabular}

a. Dependent Variable: Y

Sumber : Data primer diolah peneliti, 2021

Dari tabel 5 di atas di dapat persamaan regresi sebagai berikut: $Y=8.392+0,208 \mathrm{X}_{1}+0,423 \mathrm{X}_{2}+0,331$ $\mathrm{X}_{3}+0,547 \mathrm{X}_{4}$

1. Konstanta $=8.392$, angka tersebut menunjukkan bahwa jika X1 (produk), X2 (harga), X3 (promosi) dan X4 (lingkungan social) konstan atau $\mathrm{X}=0$, maka keputusan pembelian tetap bernilai sebesar 8,392

2. Koefisien regresi sebesar $0,208 \mathrm{X} 1$, menunjukkan bahwa produk berpengaruh positif terhadap keputusan pembelian dan bila produk meningkat satu satuan maka akan meningkatkan keputusan pembelian sebesar 0,208 dengan asumsi variabel harga, promosi dan lingkungan social tetap

3. Koefisien regresi sebesar $0,423 \mathrm{X} 2$, menunjukkan bahwa harga berpengaruh positif terhadap keputusan pembelian dan bila harga meningkat satu satuan maka akan meningkatkan keputusan pembelian sebesar 0,423 dengan asumsi variabel produk, promosi dan lingkungan social tetap

4. Koefisien regresi sebesar 0,331X3, menunjukkan bahwa promosi berpengaruh positif terhadap keputusan pembelian dan bila produk meningkat satu satuan maka akan meningkatkan keputusan pembelian sebesar 0,331 dengan asumsi variabel produk, harga dan lingkungan sosial tetap

5. Koefisien regresi sebesar $0,547 \mathrm{X} 4$, menunjukkan bahwa lingkungan sosial berpengaruh positif terhadap keputusan pembelian dan bila lingkungan sosial meningkat satu satuan maka akan meningkatkan keputusan pembelian sebesar 0,547 dengan asumsi variabel produk, harga dan promosi tetap

\section{Koefisien Korelasi}

Koefisien korelasi product moment (R) digunakan untuk mengetahui arah hubungan antara variabel dependen dengan variabel independen. Hasil analisis koefisien korelasi ganda adalah sebagai berikut : 
Tabel 6. Uji Koefiien Korelasi (R)

Model Summary ${ }^{b}$

\begin{tabular}{lrrrrr}
\hline Model & R & R Square & Adjusted R Square & Std. Error of the Estimate & Durbin-Watson \\
\hline 1 & $.709^{\mathrm{a}}$ & .503 & .482 & 1.69474 & 1.919 \\
\hline
\end{tabular}

a. Predictors: (Constant), X2, X1, X3, X4

b. Dependent Variable: Y

Sumber : Data primer diolah peneliti, 2021

Berdasarkan hasil analisis korelasi antar variabel penelitian yang disajikan pada tabel 6 , terlihat bahwa variabel independen berkorelasi signifikan terhadap keputusan pembelian dengan nilai korelasi sebesar 0,709. Ini menunjukan hubungan variabel produk , harga, promosi dan lingkungan sosial sebesar $70,9 \%$ terhadap keputusan pembelian. Sedangkan sisanya 29,1\% dipengaruhi oleh variabel lainnya yang tidak diteliti dalam penelitian ini.

\section{Koefisien Determinasi}

Koefisien determinasi (R2) pada intinya untuk mengukur seberapa jauh kemampuan viabel independen dalam menerangkan variasi variabel dependen. Penelitian ini menggunakan koefisien determinasi yang disesuaikan ( $R$-Square), karena telah memperhitungkan jumlah variabel independen dalam suatu model regresi. Hasil uji koefisien determinasi pada tabel 6 diperoleh (R square) pada output di atas sebesar 0,503. Hal ini menunjukan bahwa variabel kontribusi produk, harga, promosi, dan lingkungan sosial memberikan kontribusi pengaruh sebesar 50,3\% terhadap keputusan pembelian. Sedangkan sisanya yaitu sebesar $49,7 \%$ dipengaruhi oleh variabel lain yang tidak diteliti dalam penelitian ini seperti lokasi, dan fasilitas.

\section{Pengujian Hipotesis Parsial ( Uji T)}

Uji T bertujuan untuk menguji signifikansi pengaruh satu variabel independen secara individu terhadap variabel dependen. Hasil analisis Uji-T disajikan pada tabel berikut :.

Tabel 7. Hasil Uji T

Coefficients $^{\mathbf{a}}$

\begin{tabular}{|c|c|c|c|c|c|c|c|}
\hline \multirow{2}{*}{\multicolumn{2}{|c|}{ Model }} & \multicolumn{2}{|c|}{ Unstandardized Coefficients } & \multicolumn{2}{|c|}{ Standardized Coefficients } & \multirow[b]{2}{*}{$\mathrm{t}$} & \multirow[b]{2}{*}{ Sig. } \\
\hline & & $\mathrm{B}$ & Std. Error & Beta & & & \\
\hline \multirow[t]{5}{*}{1} & (Constant) & 8.392 & 2.644 & & & 3.174 & .002 \\
\hline & Produk & .208 & .121 & & .143 & 1.720 & .089 \\
\hline & Harga & .423 & .141 & & .264 & 2.990 & .004 \\
\hline & Promosi & .331 & .106 & & .272 & 3.114 & .002 \\
\hline & $\begin{array}{l}\text { Lingkungan } \\
\text { Sosial }\end{array}$ & .547 & .182 & & .268 & 3.001 & .003 \\
\hline
\end{tabular}

a. Dependent Variable: Y

Sumber : Data primer diolah peneliti, 2021

Dari data tabel daiatas diketahui untuk nilai t hitung produk (X1) sebesar 1.720, harga (X2) sebesar 2.990, promosi (X3) sebesar 3.114 dan lingkungan sosial (X4) sebesar 3.001. untuk menentukan $\mathrm{t}$ tabel dapat dilihat pada lampiran distribusi t, dengan menggunakan $\alpha=5 \%$ : (uji 2 sisi) dengan (df) nk-1 atau 100-5-1=94, maka di peroleh nilai t tabel sebesar 1.985 sehingga dapat di interpretasikan sebagai berikut :

a. Variabel pruduk (X1) memiliki nilai t hitung yaitu sebesar $1.720<\mathrm{t}$-tabel 1.985 dengan tingkat signifikansi sebesar 0.089 dan $\alpha$ (alpha) yang digunakan sebesar $0.05(0.089>0.05)$ sehingga hipotesis $\mathrm{H} 1$ ditolak yang artinya produk tidak berpengaruh signifikan terhadap keputusan pembelian online pakaian wanita di Kota Bima 
b. Variabel harga (X2) memiliki nilai t-hitung sebesar $2.990>$ t-tabel 1.985 dengan tingkat signifikansi sebesar 0.004 lebih kecil dari $\alpha$ (alpha) $(0.004<0.05)$ sehingga hipotesis $\mathrm{H} 2$ diterima yang berarti harga berpengaruh positif dan signifikan terhadap keputusan pembelian online pakaian wanita di Kota Bima

c. Variabel promosi (X3) memiliki nilai t-hitung yaitu sebesar $3.114>\mathrm{t}$ tabel 1.985 dengan tingkat signifikansi sebesar 0.002 lebih kecil dari $\alpha$ (alpha) $(0.002<0.05)$ sehingga hipotesis H3 diterima, yang berarti promosi berpengaruh positif dan signifikan terhadap keputusan pembelian online pakaian wanita di Kota Bima

d. Variabel lingkungan sosial (X4) memiliki nilai t hitung yaitu sebesar 3.001>t tabel 1.985, dengan tingkat signifikansi sebesar 0.003 lebih kecil dari $\alpha$ (alpha) $(0.003>0.05)$ sehingga hipotesis H4 diterima. Hasil pengujian dapat disimpulkan bahwa lingkungan sosial berpengaruh terhadap keputusan pembelian online pakaian wanita di Kota Bima

\section{Pengujian Hipotesis Simultan ( Uji F )}

Uji $\mathrm{F}$ bertujuan untuk mengetahui seberapa jauh semua variabel independen mempengaruhi variabel dependen. Hasil uji-F simultan adalah sebagai berikut :

Tabel 8. Hasil Uji F Annova

\begin{tabular}{cllrrrr}
\hline \multicolumn{8}{c}{ ANOVA $^{\mathbf{b}}$} \\
Model & Sum of Squares & Df & Mean Square & F & Sig. \\
\hline \multirow{2}{*}{1} & Regression & 276.148 & 4 & 69.037 & 24.037 & $.000^{\mathbf{a}}$ \\
\cline { 2 - 7 } & Residual & 272.852 & 95 & 2.872 & & \\
\cline { 2 - 7 } & Total & 549.000 & 99 & & & \\
\hline
\end{tabular}

a. Predictors: (Constant), lingkungan sosial, promosi, produk, harga

b. Dependent Variable: keputusan pembelian

Sumber : Data primer diolah peneliti, 2021

Berdasarkan hasil uji $\mathrm{F}$ atau $\mathrm{F}$ test diperoleh nilai F-hitung sebesar 24.037. untuk menentukan Ftabel maka digunakan table distribusi $F$ dengan menggunakan derajat $\alpha=5 \%$. Nilai df2 (n-k-1) atau 1005-1=94. Maka diperoleh nilai F-tabel sebesar 2,31. Dengan demikian dapat disimpulkan bahwa nilai Fhitung > F- tabel yaitu 24.037>2,31 sehingga hipotesis H5 diterima. Hasil pengujian dapat disimpulkan bahwa produk, harga, promosi dan lingkungan sosial secara bersama-sama (simultan) berpengaruh positif dan ssignifikan terhadap keputusan pembelian online pakaian wanita di Kota Bima.

\section{Pembahasan}

\section{Pengaruh produk terhadap keputusan pembelian online pakaian wanita di Kota Bima}

Dalam melakukan keputusan pembelian suatu produk, selain pertimbangan harga, tentunya ada pertimbangan-pertimbangan lain yang penting untuk dicermati oleh konsumen dan salah satunya adalah kualitas produk yang akan dibelinya. Berdasarkan hasil pengujian terhadap hipotesis pertama ditemukan bahwa produk berpengaruh positif dan tidak signifikan terhadap keputusan pembelian pakaian wanita secara online di Kota Bima. Hal ini menunjukkan bahwa pakaian wanita yang dibeli secara online oleh masyarakat Kota Bima tidak mampu mempengaruhi masyarakat untuk membelinya, dengan tingkat signifikan yang lebih besar dari 0,05 $(0,089>0,05)$ sehingga hal ini be lu m mampu mempengaruhi keputusan pembeli untuk membeli pakaian wanita secara online. Pakaian wanita yang ditawarkan kepada masyarakat Kota Bima pada dasarnya sangat beragam dan memiliki banyak pilihan model yang dipasarkan serta kualitas pakaian yang ditawarkan sudah cukup baik dan sesuai dengan harga yang ditawarkan oleh penjual kepada konsumen atau masyarakat Kota Bima. Tjiptono (2008:103) menyatakan, "bahwa unsur-unsur produk dipandang penting oleh konsumen dan dijadikan dasar untuk pengambilan keputusan pembelian". Hal ini sejalan dengan penelitian sebelumnya yang dilakukan oleh Nurasyiah (2021) menyimpulkan bahwa produk tidak berpengaruh terhadap keputusan pembelian online pakaian wanita. 


\section{Pengaruh harga terhadap keputusan pembelian online pakaian wanita di Kota Bima}

Berdasarkan hasil pengujian terhadap hipotesis kedua ditemukan bahwa harga berpengaruh positif yang signifikan terhadap keputusan online pakaian wanita di Kota Bima dalam pembelian pakaian wanita secara online dengan tingkat signifikan yang lebih kecil dari $0,05(0,004<0,05)$. Menurut Tjiptono (2012:315) Harga bisa diartikan sebagai sejumlah uang (satuan moneter) dan/atau aspek lain (non-moneter) yang mengandung utilitas/kegunaan tertentu yang diperlukan untuk mendapatkan sebuah produk. Oleh sebab itu, masyarakat Kota Bima lebih kritis ketika melihat dan membandingkan harga yang satu dengan yang lainnya. Dengan harga pakaian yang ditawarkan oleh penjual pakaian wanita secara online yang relatif terjangkau dan sebanding dengan manfaat dari kualitas produk yang ditawarkan oleh penjual pakaian wanita secara online.

\section{Pengaruh promosi terhadap keputusan pembelian online pakaian wanita di Kota Bima}

Selain melalui harga yang kompetitif dan produk yang berkualitas ditinjau dari kemasan maupun isinya, perusahaan juga melakukan kegiatan promosi guna memperkenalkan produknya tersebut agar lebih dikenal dan dekat dengan calon konsumen. Kegiatan-kegiatan promosi yang telah mampu mempengaruhi konsumen untuk melakukan pembelian. Promosi merupakan salah satu variabel di dalam marketing mix (bauran pemasaran) yang penting dilaksanakan oleh perusahaan dalam pemasaran produk atau jasanya. Promosi adalah arus informasi atau persuasi satu arah yang dibuat untuk mengarahkan seseorang atau organisasi kepada tindakan yang menciptakan pertukaran dalam pemasaran. Faktor promosi dapat mempengaruhi perilaku dan pemikiran konsumen dalam melakukan keputusan membeli. Berdasarkan hasil pengujian terhadap hipotesis ketiga ditemukan bahwa variabel promosi berpengaruh positif yang signifikan terhadap keputusan pembelian pakaian wanita secara online di Kota Bima dengan nilai t-hitung yang lebih besar dari nilai t-tabel dengan tingkat signifikan yang lebih kecil dari $0,05(0,002<0,05)$. Promosi merupakan variabel yang sangat berpengaruh dalam melakukan pembelian pakaian wanita secara online. Karena promosi dari sebuah perusahaan atau penjual harus memiliki daya tarik tersendiri agar masyarakat Kota Bima tertarik untuk mencari tahu dan memutuskan untuk membeli atau tidaknya sebuah pakaian. Hal ini sejalan dengan penelitian Hesty (2018) yang menyatakan promosi merupakan media untuk mengenalkan, mengajak, mempersuasi, dan mempengaruhi konsumen untuk mempertimbangkan, membeli dan konsumsi produk yang ditawarkan oleh perusahaan atau pemasar.

\section{Pengaruh lingkungan sosial terhadap keputusan pembelian online pakaian wanita di Kota Bima}

Berdasarkan hasil pengujian terhadap hipotesis keempat ditemukan bahwa lingkungan sosial berpengaruh positif dan signifikan terhadap keputusan pembelian masyarakat Kota Bima terhadap pakaian wanita secara online dengan nilai t-hitung yang lebih besar dari t-tabel dengan tingkat signifikan sebesar 0,003 lebih kecil dari 0,05 $(0,003<0,05)$. Karena lingkungan sosial masyarakat Kota Bima ikut mempengaruhi masyarakat Kota B i ma dalam melakukan keputusan pembelian terhadap pakaian wanita yang dijual secara online hal ini sejalan dengan teori yang dikemukakan oleh Peter dan Olson dalam Hartiyani dkk (2017) berpendapat bahwa lingkungan Sosial adalah semua interaksi sosial antara masyarakat, baik secara langsung, misalnya berdiskusi dengan seorang teman, maupun secara vicarious, yaitu pengamatan mengenai apa yang sedang dilakukan atau dikenakan orang lain. Seseorang belajar sesuatu melalui dua jenis interaksi tersebut. Oleh sebab itu, kecenderungan dalam mengikuti apa yang dibeli dan dilakukan oleh orang-orang disekitar masyarakat Kota Bima mampu mempengaruhi siapapun masyarakat Kota Bima dalam memutuskan membeli atau tidaknya pakaian wanita yang dipasarkan secara online.

Pengaruh Produk, Harga, Promosi dan Lingkungan Sosial terhadap Keputusan Pembelian Online Pakaian Wanita di Kota Bima 
Berdasarkan hasil pengujian hipotesis secara simultan ditemukan bahwa Produk, Harga, Promosi dan Lingkungan Sosial berpengaruh signifikan terhadap Keputusan Pembelian Online Pakaian Wanita di Kota Bima dengan nilai F-hitung yang lebih besar dari F-tabel dengan tingkat signifikan sebesar 0,000 lebih kecil dari $0,05(0,000<0,05)$. Hal ini mengindikasikan bahwa konsumen online shop di Kota Bima sebelum memutuskan pembelian pakaian secara online terlebih dahulu memperhatikan kualitas dari, konsumen juga akan melakukan perbandingan terhadap harga dari produk yang akan mereka beli. Selain memperhatikan kualitas produk, harga, konsumen juga melihat cara promosi dan kondisi lingkungan sosial. Karena lingkungan sosial masyarakat Kota Bima ikut mempengaruhi dalam melakukan keputusan pembelian terhadap pakaian wanita yang dijual secara online hal ini sejalan dengan penelitian sebelumnya dari Gusrita, Desy (2019) bahwa Produk, Harga, Promosi dan Lingkungan Sosial berpengaruh signifikan terhadap keputusan pembelian online pakaian wanita di Kota Padang. Selanjutnya penelitian Nurasyiah (2021) menyatakan bahwa nilai F untuk variabel produk, harga, promosi, dan lingkungan sosial secara bersama-sama berpengaruh terhadap keputusaan pembelian online pakaian wanita.

Semakin baik strategi pemasaran yang digunakan oleh perusahaan maka akan semakin meningkatkan keputusan pembelian. Implikasi bagi perusahaan online shop atas hasil analisis adalah perlu adanya perhatian utama untuk variabel produk.variabel produk memiliki pengaruh paling sedikit terhadap keputusan pembelian karena variabel ini mempunyai pengaruh pada harga sehingga menentukan keputusan pembelian konsumen pada online shop.

\section{SIMPULAN}

\section{Kesimpulan}

1. Produk berpengaruh positif dan tidak signifikan terhadap keputusan pembelian online pakaian wanita di Kota Bima. Hal ini berarti semakin baik kualitas produk maka semakin tinggi pula keputusan konsumen melakukan pembelian online .

2. Harga berpengaruh positif dan signifikan terhadap keputusan pembelian online pakaian wanita di Kota Bima. Hal ini berarti apabila harga produk bervariatif maka semakin tinggi keputusan konsumen melakukan pembelian online

3. Promosi berpengaruh positif dan signifikan terhadap keputusan pembelian online pakaian wanita di Kota Bima. Hal ini berarti semakin baik promosi yang dilakukan oleh onlineshop dalam menarik minat konsumen, maka semakin tinggi keputusan konsumen melakukan pembelian online.

4. Lingkungan sosial berpengaruh positif dan signifikan terhadap keputusan pembelian online pakaian wanita di Kota Bima. Hal ini berati semakin baik dari lingkungan sosial maka semakin tinggi pula keputusan konsumen melakukan pembelian online.

5. Produk, Harga, Promosi dan Lingkungan sosial secara simultan berpengaruh positif dan signifikan terhadap keputusan pembelian online pakaian wanita di Kota Bima. Hal ini menunjukkan bahwa apabila onlineshop atau marketplace memberikan produk yang berkualitas dengan harga yang terjangkau serta melakukan promosi yang menarik minat pembeli, maka akan semakin meningkat keputusan konsumen melakukan pembelian online

\section{Saran}

1. Dalam meningkatkan produk, toko pakaian yang menjual secara online disarankan menyediakan variasi produk yang lengkap, menjual produk-produk yang popular, dan menyediakan informasi produk yang lengkap bagi konsumen. Selalu memberikan servis yang baik, ranmah dalam menjawab pertanyaan-pertanyaan konsumen.

2. Dalam meningkatkan keputusan pembelian, maka sebaiknya menjalankan marketing mix dengan baik seperti menyediakan variasi pakain yang sedang trend, selain itu harus disesuaikan dengan harga dengan kualitas barang, dan melakukan promosi akan keunggulan atau kelebihan yang online shop 
kita miliki dibanding dengan online shop lainya. Sehingga keputusan konsumen tetap terjaga dengan baik, seperti menyediakan waktu khusus secara online untuk menyelesaikan masalah konsumen.

\section{DAFTAR PUSTAKA}

Abdullah, Thamrin dan Francis Tantri.2016.Manajemen Pemasaran.Jakarta: Rajawali Pers. Anwar, Prabu Mangkunegara. 2012. Perilaku Konsumen. Edisi Revisi. Bandung: Refika Aditama Budanti, Hartiyani Sadu, Mintasih Indriayu dan M.Sabandi.2017.Pengaruh Lingkungan Sosial Dan Gaya Hidup Terhadap Perilaku Konsumsi Mahasiswa Program Pendidikan Ekonomi FKIP UNS, Jurnal Ekonomi Manajemen .

Buchari Alma, 2011, Manajemen Pemasaran dan Pemasaran Jasa,. Alfabeta, Bandung

Febriana, Merry Bella, Edy Yulianto dan Sunarti. 2016. Pengaruh Bauran Pemasaran Terhadap Keputusan Pembelian (Survey Kepada Konsumen Sepatu Merek Converse di Kota Malang. Jurnal Administrasi Bisnis.Vol.32 No.2.

Ghozali. 2016. Aplikasi Analisis Multivariete Dengan Program IBM SPSS. Semarang: Badan Penerbit Universitas Diponegoro

Gusrita, Desy. 2019 Pengaruh Marketing Mix dan Lingkungan Sosial terhadap Keputusan Pembelian Online Pakaian Wanita di Kota Padang. Fakultas Ekonomi. Jurnal Erogen Vo. 1 No. 4.

Indriyo Gitosudarmo, 2012, Manajemen Pemasaran, Yogyakarta, BPFEYogyakarta

Kotler, Philip dan Kevin Lane Keller. 2013. Marketing Management. New Jersey: Prentice.

Kotler, Philip dan Amstrong, Gary, 2014, Principles of Marketin, 12th Edition, Jilid 1 Terjemahan Bob Sabran Jakarta : Erlangga.

Lupiyoadi, Rambat. 2014. Manajemen Pemasaran Jasa Berbasis Kompetensi. Edisi ke-3. Jakarta: Salemba Empat

Malau Herman, 2017. Manajemen Pemasaran. Alfabeta, Bandung

Marendra, I Gede.2018. Pengaruh Bauran Pemasaran (Produk, Harga, Lokasi, dan Promosi) Terhadap Keputusan Pembelian Konsumen di Minimarket (Alfamart atau Indomaret) (Studi Kasus di Unuversitas Pamulang. Jurnal Pemasaran Kompetitif.Vol.1 No.3.

Peter dan Olson. 2013. Perilaku Konsumen dan Strategi Pemasaran. Jakarta: Salemba Empat

Pertiwi, Marina Intan, Edy Yulianto dan Sunarti.2016. Pengaruh Bauran Pemasaran Terhadap Keputusan Pembelian (Survey Pada Konsumen Baker's King Donuts \& Coffee di MX Mall Malang. Jurnal Administrasi Bisnis.Vol.37 No.1.

Sekaran, U. dan Bougie, R. 2013. Research Methods for Business: A Skill-Building Approach. Sixth Edition. New York: Wiley

Sugiyono. 2016. Metode Penelitian Kuantitatif, Kualitatif dan R\&D. Bandung: Alfabeta

Syahrial, Yusroni Akhmad.2015.Analisis Pengaruh Produk,Harga,Promosi dan Lokasi Terhadap Keputusan Pembelian Pada UD. Aneka Karya Glass di Surakarta.Unpublished Dissertation.Surakarta: UM.

Tan, Erwin Rediono.2011. Pengaruh Faktor Harga, Promosi dan Pelayanan Terhadap Keputusan Konsumen Untuk Belanja di Alfamart Surabaya. .Jurnal Kewirausahaan Vol.5 No.2.

Tjahjono, Amelia, Hatane Semuel Ritzky Karina M. R. Brahmana.2013. Analisis Marketing Mix, lingkungan Sosial, Psikologi Terhadap keputusan Pembelian Online Pakaian Wanita. .Jurnal Manajemen Pemasaran Petra.Vol.1 No.2.

Utami, Hesty Nurul dan Iqbal F.A.F.2018. Pengaruh Bauran Pemasaran Terhadap Perilaku Online Shopping:Perspektif Pemasaran Agribisnis. Jurnal Ecodemika.Vol.2 No1. 